Discussion Paper No. 14-069

Short-run Fertility Effects of Parental Leave Benefits:

Evidence from a Structural Model

Holger Stichnoth

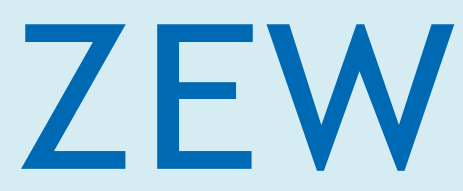

Zentrum für Europäische Wirtschaftsforschung $\mathrm{GmbH}$

Centre for European

Economic Research 
Discussion Paper No. 14-069

\title{
Short-run Fertility Effects of Parental Leave Benefits: \\ Evidence from a Structural Model
}

\author{
Holger Stichnoth
}

Download this ZEW Discussion Paper from our ftp server:

http://ftp.zew.de/pub/zew-docs/dp/dp14069.pdf

Die Discussion Papers dienen einer möglichst schnellen Verbreitung von neueren Forschungsarbeiten des ZEW. Die Beiträge liegen in alleiniger Verantwortung der Autoren und stellen nicht notwendigerweise die Meinung des ZEW dar.

Discussion Papers are intended to make results of ZEW research promptly available to other economists in order to encourage discussion and suggestions for revisions. The authors are solely responsible for the contents which do not necessarily represent the opinion of the ZEW. 


\title{
Short-run Fertility Effects of Parental Leave Benefits: Evidence from a Structural Model
}

\author{
Holger Stichnoth* \\ ZEW Mannheim
}

September 21, 2014

\begin{abstract}
Based on a structural model of fertility and female labour force supply with unobserved heterogeneity and state dependence, we evaluate the 2007 reform of parental leave benefits in Germany, which replaced a flat, means-tested benefit by a generous earnings-related transfer. The model predicts a short-term fertility effect of about $4 \%$, which is consistent with recent quasi-experimental evidence. The fertility effect is strongest for first births and increases with income. We use the model for a number of counterfactual policy experiments in which we vary the generosity of parental leave benefits.
\end{abstract}

JEL classification: C25; C53; J13; J22

Keywords: Fertility; female labour supply; family policy; parental leave; latent class models; state dependence

\footnotetext{
${ }^{*}$ Corresponding author. Address: ZEW Centre for European Economic Research, P.O. Box 103443, 68034 Mannheim, Germany. E-Mail: stichnoth@zew.de. Phone: +49 (0)621 1235-362. Work on this paper began as part of a project financed by the German Federal Ministry of Finance (BMF) and the Federal Ministry of Family Affairs, Senior Citizens, Women and Youth (BMFSFJ). The views expressed in the paper are those of the author and not necessarily those of the two ministries. Raphael Abiry, Holger Bonin, Karsten Reuss (all at ZEW Mannheim) as well as Christina Boll, Nora Reich, Christina B. Wilke (all at HWWI Hamburg), Marc-André Nehrkorn-Ludwig, Reinhold Schnabel (both at the University of Duisburg-Essen), Irene Gerlach, Inga Laß (both at FFP Münster) and Karsten Hank (University of Cologne) participated in the overall project and provided valuable input into the development of the present model. The manuscript benefitted from comments by François Laisney and from discussions with seminar participants at ZEW Mannheim, NIW Hannover, the Institute for Fiscal Studies (London) and ISER/University of Essex, workshop participants at the ZEW Workshop on Family Economics (November 2013), the ZEW Workshop on Family Policy in Germany (February 2014) and the 4th Workshop "Arbeitsmarkt und Sozialpolitik" at ifo Dresden as well as conference participants at the meetings of the IIPF (Lugano) and the EALE (Ljubljana). Financial support through the SEEK programme of the State of Baden-Württemberg is gratefully acknowledged.
} 


\section{Introduction}

Almost all OECD countries have a system of paid parental leave in place. During parental leave, parents are guaranteed their pre-birth jobs and typically receive some kind of financial support. Countries differ in the duration of parental leave and the level and design of benefit payments (Thévenon and Solaz, 2013).

In 2007, Germany, which had long been a classic example of a "male breadwinner" model, took many observers by surprise and reformed its parental leave regulations to bring them closer to the "Nordic model". By shortening the entitlement period from 24 to 12 months (14 months if both parents go on parental leave for at least two months), the reform set clear incentives for a faster return to work. Moreover, the reform replaced the previous flat and means-tested transfer of 300 euros with a benefit that depends on previous earnings and can reach up to 1800 euros per month. The changes were introduced against a background of low fertility (especially among women with a tertiary education) and weak labour market attachment of mothers.

Several recent studies have evaluated the reform using quasi-experimental designs. Bergemann and Riphahn (2011a;b), Wrohlich et al. (2012), Kluve and Tamm (2013) and Kluve and Schmitz (2014) show that the reform has had the intended effect of speeding up mothers' return to employment. ${ }^{1}$ The evidence concerning the fertility effects is more mixed. Raute (2014) finds that the new earnings-related parental leave benefit has increased fertility, especially for women in the middle and in the upper end of the income and education distributions. Bujard and Passet (2013) find that the probability of a second birth was not significantly different in the periods 2003-2006 and 2007-2008, while CyganRehm (2013) finds no evidence that the probability of another birth within 36 months has changed because of the reform; however, she does find evidence that the timing of

\footnotetext{
${ }^{1}$ Schönberg and Ludsteck (2014) find that earlier reforms that increased the duration of parental leave reduced mothers' employment in the short run, with small longer-run effects. Dustmann and Schönberg (2012) show that the expansions had little effect on child outcomes in the long run.
} 
births within the 36-months window has been affected. ${ }^{2}$

The quasi-experimental studies face the challenge that the reform in parental leave benefits was not the only change in family policy in Germany in recent years. Beginning in 2004, a major effort has been made to increase the availability of public childcare for children below the age of three. Starting from a low level, the number of places has been increased, and since August 1st, 2013, all children older than 12 months are entitled to subsidized public childcare. The increase affected different regions and different groups of the population differently, and may thus contaminate the difference-in-differences strategies used to evaluate the 2007 reform of parental leave benefits.

The main contribution of the present paper is to estimate a structural model that allows isolating the effects of the new parental leave benefits scheme from the effects of other developments during the same time. A structural approach also has the advantage that the effects of different components of the reform can be disentangled, and that the model can be used to simulate counterfactual policy experiments.

Our model builds on the work of Haan and Wrohlich (2011). In each period, women choose among three employment states (non-employment, part-time, full-time) and decide whether to have a child or not. The labour supply of the partner is assumed to be exogenous, which given observed employment patterns is a reasonable approximation. The model allows for state dependence and takes into account unobserved heterogeneity in fertility preferences, which is modelled through a latent class approach. Disposable incomes at each choice alternative are simulated using a detailed representation of the tax-transfer system. The model is estimated using data from the German Socio-Economic Panel (SOEP) for the years 2005-2010. Mainly due to the reform in parental leave benefits in 2007, there has been substantial variation in fertility and labour supply incentives during this period, both over time and across households.

\footnotetext{
${ }^{2}$ Tamm (2013) and Neugart and Ohlsson (2013) show that some women tried to shift the timing of births around the day the reform took effect. See Cygan-Rehm (2014) for a survey on the fertility effects of the 2007 reform.
} 
We complement the standard SOEP data set with information from the recent extension "Familien in Deutschland" (FiD, "Families in Germany") that has direct information on whether parents are rationed in their access to public childcare. The new data allow us to obtain a more realistic picture of childcare costs and hence disposable income at each choice alternative.

We use the estimated parameters to predict fertility and female labour supply outcomes under both the actual tax-transfer system of 2012 and several counterfactual changes to it. In addition to evaluating parental leave benefits and public childcare subsidies, we study the fertility and female labour supply effects of child benefits and income tax splitting, two other important family-related policies. Public spending on the four measures in Germany totals around 70 billion euros per year (BMFSFJ, 2008).

We find that the 2007 reform in parental leave benefits has a positive effect on fertility. If the rules had still been those of the pre-reform period, the number of births in 2012 would have been lower by about 24000 , which corresponds to $4 \%$ of actual births in that year. The effect is strongest for first births and is driven by women from the third and fourth quartiles of the income distribution, many of whom were not eligible for the means-tested pre-2007 benefits and receive substantial transfers under the new regime. Both the size of the overall effect and the heterogeneous response pattern are consistent with the recent quasi-experimental study by Raute (2014).

As for the other measures, child benefits increase the fertility rate but have a small effect on female labour supply. In contrast, income tax splitting reduces work incentives for the secondary earner without any significant effect on the number of births. In our simulations, subsidized public childcare is found to increase female labour supply at the expense of fertility. However, the negative fertility effect is driven by the one-year horizon of the model.

Finally, we use the structural model for a series of policy experiments in which we vary the generosity of parental leave benefits. The model predicts that doubling the level of 
benefits would have led to 150000 additional births in 2012, roughly a quarter of actual births in that year. Note, however, that the one-year horizon of the model does not allow distinguishing between timing effects and effects on completed fertility, so this increase is most likely an upper bound. The increase in the number of births is found to be associated with fiscal costs of about 17.5 billion euros per year. The number takes into account both direct spending on parental leave benefits and the reactions of income tax revenue, social security contributions, as well as the interactions with other transfers. Of course, given that the simulation is for a level of benefits much higher than what we observe in the data, the prediction can only indicate a rough order of magnitude.

As noted, the paper closest to ours is by Haan and Wrohlich (2011). They estimate a structural model for fertility and female labour supply for the years 2000-2006, i.e. the period before the reform of parental leave benefits. Laroque and Salanié (2013) estimate a similar model for France. Wrohlich et al. (2012) estimate a structural labour supply model and use it to evaluate the new German parental leave benefits scheme. They focus on women's return to work, however, and do not endogenize the fertility decision. Lalive et al. (2014) develop a job search model to study how the design of parental leave in Austria (both benefits and duration) affects mothers' return to work. To our knowledge, ours is the first structural model that analyzes the effects of parental leave benefits on both female labour supply and fertility.

Bick (2013) and Domeij and Klein (2013) estimate life-cycle models of female labour supply and fertility using data for Germany. They use the models to simulate the effects of changes in childcare subsidies. Adda, Dustmann, and Stevens (2011) additionally endogenize the occupation choice. They run a counterfactual policy experiment in which they double the amount of child benefits. Fehr and Ujhelyiova (2012) calibrate an overlapping generations model to the German economy of 2007/2008. They simulate stylized reforms in child benefits and several changes to the taxation of family income. ${ }^{3}$

\footnotetext{
${ }^{3}$ In addition to these structural models, there is also a number of recent quasi-experimental papers on the fertility effects of family policy measures: Lalive and Zweimüller (2009) study how two reforms in the duration of the Austrian parental leave scheme affected mothers' return to work and (higher-order)
} 
The rest of the paper is organised as follows. Section 2 outlines the model, explains the simulation of disposable incomes and illustrates the fertility and employment incentives generated by the tax-transfer system. Section 3 describes the data, while Section 4 documents the estimated parameters, the fit of the model and results from an out-of-sample validation. Section 5 reports findings from a series of counterfactual policy experiments in which we compare the pre- and post-2007 rules of the parental leave benefits, vary the level of generosity of the current system, and switch off selected family policy measures while keeping the rest of the tax-transfer-system in place. Section 6 concludes.

\section{Model}

\subsection{Fertility and labour supply decisions}

We model only cohabiting couples (regardless of marital status), as our data set shows that very few women live alone in the year the child is born. We adopt a unitary framework, i.e. couples maximize a joint utility function.

Households are indexed by $i$ and consider in each period $t$ (taken to be a year) whether to have a child; they also choose the employment status of the woman (not employed, part-time, full-time). There are thus $J=6$ mutually exclusive options to choose from.

We have to be careful when defining how the employment status enters the choice set. In Germany, women are not allowed to work in the first eight weeks after childbirth, and very few women work while the child is younger than one year, which means that there is little variation that our model could explain. The employment status for women who give birth in year $t$ is therefore measured 12 months after birth. For the women who do

fertility. Milligan (2005) and Azmat and González (2010) investigate the fertility effects of income tax reforms, while Brewer et al. (2012) studies an increase in per-child welfare spending and González (2013) analyzes the effects of the introduction of a universal child benefit in Spain. Cohen et al. (2013) show that fertility rates in Israel have been responsive to various changes in the tax-transfer-system that affect the costs of a child. 
not give birth, the employment status is measured in March. ${ }^{4}$

The utility of option $j$ for household $i$ in period $t$ is given by $U_{i j t}=V_{i j t}+\varepsilon_{i j t}$. $V_{i j t}$ is the component of utility that is observed by the econometrician (up to a parameter vector $\beta$ ); we assume the following, linear-in-parameters specification:

$$
V_{i j t}=\beta_{i}^{y} y_{i j t}+\beta^{y L} y_{i j t} L_{j t}+\beta_{i}^{L} L_{j t}+\beta^{L L} L_{j t}^{2}+\beta_{i}^{F} F_{j t}+\beta^{F L} F_{j t} L_{j t}+\beta^{F y} F_{j t} y_{i j t}
$$

where $y_{i j t}$ is the natural logarithm of (monthly) disposable household income, $F_{j t} \in\{0,1\}$ indicates whether a child is born, and $L_{j t}$ is female non-market time. We assume that the theoretical maximum of market work per week is 80 hours (five days per week times a maximum of 16 hours per day). We assign 20 hours/week to part-time employment, and 40 hours/week to full-time employment. The corresponding non-market time is therefore 60 and 40 hours per week, respectively. For women who are not employed, non-market time is 80 hours per week. We multiply these numbers by the average number of weeks per month, as we define $L_{j t}$ on a monthly basis.

We account for both observed and unobserved heterogeneity in preferences. The observed characteristics included in the model are the number of existing children, the age of both partners, their education, marital status, immigration background, residence in East Germany, working as a civil servant, size of the house or apartment, self-reported concerns about the household's financial situation, and self-reported health concerns. They enter the utility function through interactions with disposable income, non-market time and the fertility indicator.

To capture state dependence, preferences also depend on the employment and fertility choices of the previous period $\left(L_{i, t-1}, F_{i, t-1}\right)$. Following Wooldridge $(2005)$, we deal with the initial conditions problem by conditioning on employment and fertility in the first observation period for each household.

\footnotetext{
${ }^{4}$ Alternatively, we measure employment at the month of the interview for the women who do not give birth. Since the employment status of women who do not give birth varies little over the year, this does not matter much for the results.
} 
Unobserved heterogeneity is captured through a random coefficient on the fertility variable. We allow for $M$ discrete types in the population, and estimate their shares $\pi_{m}$ along with the other parameters of the model. This random coefficient framework is equivalent to an error components model with a time-invariant individual-specific component. We assume that the remaining error component is independently and identically extremevalue distributed. The model is flexible enough to allow for correlations both across time and across alternatives and avoids the restrictive substitution patterns implied by the standard logit model.

The probability that a household $i$ of type $m$ makes a sequence of choices $\left(k_{t}\right)_{t=1, \ldots, T_{i}}$ (where $T_{i}$ is the number of choice situations observed for household $i$ ) is given by

$$
L_{i}\left(\beta_{m}\right)=\prod_{t=1}^{T_{i}}\left[\frac{\exp \left(x_{i k_{t} t}^{\prime} \beta_{m}\right)}{\sum_{r=1}^{J} \exp \left(x_{i r t}^{\prime} \beta_{m}\right)}\right]
$$

As we do not observe a household's type, its log-likelihood contribution is the log of the weighted sum of these probabilities over all types:

$$
L L_{i}=\ln \left(\sum_{m=1}^{M} \pi_{m} \prod_{t=1}^{T_{i}}\left[\frac{\exp \left(x_{i k_{t} t}^{\prime} \beta_{m}\right)}{\sum_{r=1}^{J} \exp \left(x_{i r t}^{\prime} \beta_{m}\right)}\right]\right)
$$

The sample log-likelihood is the sum of these $L L_{i}$ over the $N$ households in our sample.

\subsection{Simulation of disposable income}

To estimate the parameters of the utility function, disposable household income $y_{i j t}$ must be known (or rather simulated) not just for the choice the households actually made, but also for all other potential choices. The simulation takes into account income taxation and the most important transfers, including welfare benefits, housing benefits, parental leave benefits and child benefits. Both taxes and transfers depend on gross earnings and income from other sources (such as capital income or rental income) as well as other household characteristics such as marital status or the presence of children. 
Figure A.1 in the Appendix illustrates the simulation of disposable income for an example household (married couple, one child aged 12 months; monthly cost for rent and heating: 393 euros). ${ }^{5}$ The horizontal axis shows the gross earnings of the male partner, the vertical axis measures monthly disposable household income. By assumption, the woman in the example household is not employed. The figure illustrates that the decision not to be employed corresponds to a different disposable income depending on the earnings of the male partner. The same holds for the two other options not shown in the figure, i.e. parttime and full-time work. Even for the example household shown here (for whom all other characteristics except for male earnings are held constant), disposable income in the nonemployment state varies between 1800 and about 3500 euros per months in a given year post-2007. In the actual estimation, there is additional variation as the women observed in the data have different gross hourly wages and household characteristics. ${ }^{6}$ The figure also illustrates that there is substantial variation across time, which is mainly driven by the 2007 reform of parental leave benefits.

Figure A.2 illustrates how the presence of a child can influence disposable income. We vary weekly hours of work of the female spouse along the horizontal axis. The vertical axis shows the difference in disposable income between a couple with a child aged twelve months and a couple without a child, for otherwise identical household characteristics. ${ }^{7}$ The figure shows that especially since the reform of parental leave benefits in 2007, (female) hours of work and the presence of a child aged twelve months strongly interact in the determination of disposable income. If the woman works less than 30 hours per

\footnotetext{
${ }^{5}$ The value for rent and heating is relevant for calculating social assistance and housing benefits. The value assumed here corresponds to the average value among recipients of social assistance in July 2011 (Bundesagentur für Arbeit, Durchschnittliche Höhe der Zahlungsansprüche für Leistungen für Unterkunft und Heizung nach Größe der Bedarfsgemeinschaft).

${ }^{6}$ For women who do not work and for whom we do not observe earnings, we impute wage offers based on a model that accounts for selection into employment (Heckman, 1979). The results are documented in Tables A.4 and A.5 in the Appendix.

${ }^{7}$ The example household is a married couple in which the male partner is assumed work 40 hours per week, for an hourly gross wage of 16 euros. We follow Haan and Wrohlich (2011) and assume that the hourly wage of the woman is 12.40 euros. Her monthly net earnings in the previous year (relevant for the calculation of parental leave benefits) are set to 2000 euros. Costs for rent and heating are assumed to be 334 euros (no child) and 393 euros (one child) per month.
} 
week, the household is entitled to parental leave benefits, which can be a substantial amount. Prior to 2007, the amount was much lower and, due to the means testing, was hardly relevant for many households.

Additional incentive effects arise from the temporal and regional variation in the cost and availability of childcare - public childcare has long been in short supply in Germany, in particular for children aged below 3. This variation in (expected) childcare costs is not included in the two previous figures, but does enter the simulated disposable incomes used in the estimation of the model. We assume that the amount of external childcare required is a function of parents' employment status. More precisely, we make it dependent on $\min \left\{h_{m}, h_{f}\right\}$, where $h$ are weekly hours of work and $m$ and $f$ index the male and female partner. If the minimum is 0 , no external childcare is needed. If the minimum is 20 or 40 hours, parents need to organize the corresponding amount of childcare for all children up to the age of 6 . Assuming a fixed relationship between parental working hours and childcare reduces the number of choice variables in the model, and provides a reasonable approximation to observed patterns of childcare use.

For each household, we compute expected childcare costs in each choice alternative. With a certain probability, the household is "rationed", i.e., cannot find a subsidized childcare slot. Based on data from the 2010 SOEP extension "Familien in Deutschland" (FiD, "Families in Germany"), which has detailed information on childcare use and costs, parents are defined to be rationed if they answer that they do not send their child to public childcare because they could not get a place, because the distance was too great or because the opening hours do not correspond to their needs. We estimate the rationing probability as a function of the region and the age of the child, and then impute the probabilities to the SOEP households. As Table A.1 in the Appendix shows, the probability of not finding an adequate slot in public childcare is higher in West Germany and for younger children. Following Müller et al. (2013), we assume that parents who cannot find a subsidized childcare slot have to rely on privately organized childcare, at a rate of 6.40 euros per hour. 
Parents who do have access to public childcare pay a (heavily subsidized) monthly fee, which depends on household income, the age of the child, the region, whether siblings are already in childcare, and whether the child is in part-time or full-time care. Note that for some parents (e.g., with low income or in specific regions), parental fees can be zero. Estimation results (from Tobit models) are shown in Table A.2 in the Appendix.

\section{Data}

The model is estimated using data from the German Socio-Economic Panel. The SOEP, which started in 1984, is a longitudinal survey of private households, with a rich set of information on personal and household characteristics. ${ }^{8}$

We use the SOEP waves 2004-2011 to study choices in the years 2005-2010. The last wave cannot be used because monthly information on the employment status is only available retrospectively for the previous year. The first wave is used to construct previous net earnings (relevant for the simulation of parental leave benefits) when modelling the choice in 2005. As the SOEP is available for all years since 1984, we could in principle go further back in time. However, we choose to focus on the period after the major labour market reforms of 2005, which in our view is the relevant environment for counterfactual policy experiments that are informative for today's economic policy.

We restrict the sample to women aged 23-45 who live with a partner and who are neither in education nor self-employed. We focus on fertility and labour supply decisions of couples because in our data very few children are born to women who do not live with a partner. Our sample includes both married and unmarried couples.

Applying these criteria (and after listwise deletion of missing values), we are left with 8329 household-year observations for 2641 households. The sample is an unbalanced panel. There are 464 households with information for six consecutive choice situations,

\footnotetext{
${ }^{8}$ See Wagner et al. (2007) for a detailed description.
} 
while 614 households are modelled in only one choice situation (but are observed in three adjacent years, see above). Table A.3 in the Appendix shows summary statistics for the sample. As explained above, we impute expected childcare costs for each household at each choice alternative. We predict that full-time care for a child below the age of 3 will on average cost 311 euros per month for the households in our sample. Full-time care for older children will cost 152 euros per month. For part-time care, the average costs are 196 and 100 euros, respectively. As noted above, the costs differ by region, household income, and number of siblings.

Table A.6 in the Appendix documents that a woman's employment status is highly dependent on whether she gave birth in the previous year. In this case, only $6 \%$ of women in our sample work full time, while for women who did not give birth twelve months ago the share is $33 \%$. Women in West Germany and women who have other children tend to work less often twelve months after childbirth. For men, the employment status is only weakly related to the birth of a child (Table A.7). Twelve months after a child is born, $81 \%$ of men in East Germany and $87 \%$ of men in West Germany work full time. This suggests that treating male labour supply as exogenous is a reasonable approximation. ${ }^{9}$

\section{Estimation Results}

Full estimation results are documented in Table A.8 in the Appendix. The first column shows results from a multinomial logit model without unobserved heterogeneity, while the second column reports the estimates from a latent-class model with two discrete mass points for the fertility coefficient.

We will not discuss the long list of parameter estimates here, which are hard to interpret

\footnotetext{
${ }^{9}$ Note that the table refers to the entire estimation period 2005-2010. We find evidence that after 2007 , fathers' labour supply tends to react more strongly to the birth of a child, which is in line with the incentives set by the two extra "daddy months" that are part of the post-2007 rules for parental leave benefits. Using data from the German Microcensus, Geisler and Kreyenfeld (2012) show direct evidence that use of parental leave by fathers has increased in Germany.
} 
individually given the non-linear model and the many interactions between the variables. We therefore choose to focus on model fit and on out-of-sample validation for assessing the model.

The only individual parameter estimates that do merit discussion are the results concerning the unobserved heterogeneity in fertility preferences. The difference in the fertility coefficient between the two groups is estimated to be 2.08. The (transformed) share parameter is estimated to be -0.4215 , which corresponds to a share of $39.6 \%$. However, the share parameter is not statistically significant.

We also tried models with three and four mass points, but found that the share parameters were equally insignificant. Moreover, based on the Akaike Information Criterion (AIC), these models perform less well than the model with two mass points. ${ }^{10}$ In these models, not only the share parameters but also many of the differences between the types turn out to be statistically insignificant.

We conclude from this that after including a long list of observed characteristics in the model, the iid assumption underlying the conditional logit model may be a reasonable approximation. The results reported in the remainder of this paper are therefore based on the conditional logit specification without unobserved heterogeneity. This has the advantage that the simulations can be based on the analytical transition probabilities derived by Bonin and Schneider (2006).

Table 1 shows that the model predicts the observed choices quite well. Part of this fit is obtained simply by construction. The multinomial logit model has the property that it equates the observed and predicted averages of all covariates. Since the model includes an indicator variable for whether a child is born in a particular choice alternative, the perfect fit that we observe here follows directly from the assumptions. ${ }^{11}$ Since the birth

\footnotetext{
${ }^{10}$ The values of the AIC are 10946 (two mass points), 10951 (three mass points), 10954 (four mass points). The conditional logit model has an AIC of 10962.

${ }^{11}$ The birth rate is defined as the number of births divided by the number of women in the sample. The value of $5.6 \%$ in our sample is close to the official figure of $3.7 \%$ reported by the Federal Statistical Office for the year 2010. The latter figure uses all women aged 15-49 in the denominator, while we restrict our sample to women aged 23-45 and living in couple households, which explains why we find a
} 
indicator is interacted with several other variables, we also find a perfect fit for the two subgroups (East vs. West, other children yes/no) shown here.

Studying the fit for the participation rate is more meaningful as the model includes female non-market hours at each choice alternative but not a dummy for participation. As a consequence, the mean of the female hours variable is predicted by construction, but the same is not true for the three individual working hours categories. We find that the model predicts the participation rate quite well, both in the overall sample and for different subgroups. ${ }^{12}$

Table 1: Model fit

\begin{tabular}{|c|c|c|c|c|}
\hline & \multicolumn{2}{|c|}{ Participation rate } & \multicolumn{2}{|c|}{ Birth rate } \\
\hline & Data & Model & Data & Model \\
\hline East & $79.8 \%$ & $81.7 \%$ & $5.9 \%$ & $5.9 \%$ \\
\hline West & $70.9 \%$ & $70.4 \%$ & $5.6 \%$ & $5.6 \%$ \\
\hline Already has children & $67.8 \%$ & $66.6 \%$ & $5.0 \%$ & $5.0 \%$ \\
\hline No other children & $86.9 \%$ & $90.3 \%$ & $7.3 \%$ & $7.3 \%$ \\
\hline Total & $72.9 \%$ & $72.9 \%$ & $5.6 \%$ & $5.6 \%$ \\
\hline
\end{tabular}

Source: Own calculations based on SOEP 2005-2010. N=8329 for 2641 unique households. Birth rate $=$ number of births divided by the number of women aged $23-45$.

Since we have several years of data for the estimation, we explore how the model's predictions perform out of sample. Results are reported in Table 2. The first row corresponds to the last row of Table 1, i.e. it shows the fit of the model when the estimation and the prediction sample coincide. In the other rows, we estimate the model only on a subset of years and compare the predictions of the model with the actual observations for later years. As expected, these out-of-sample predictions are less exact than the within-sample fit. However, predicted and observed values are still reasonably close. As expected, we find in most cases that the longer the estimation period compared to the prediction period, the better the predictions. Since our actual simulations are be based slightly higher birth rate.

${ }^{12}$ The predicted joint distribution of the participation and birth indicators is also very close to the distribution observed in the sample. For the joint distribution of the hours variable and the birth indicator, the correspondence is again exact by construction as the model includes the interaction of both variables. 
on the entire estimation period from 2005-2010 and will make predictions for a single year (2012), the most informative row of Table 2 is the last one, where observations and predictions are particularly close. Moreover, the simulations are based on a comparison between the baseline simulation for 2012 and different counterfactual policy experiments in which certain policy measures in the 2012 tax-transfer system will be switched off. By a difference-in-differences argument, this means that not exactly predicting the levels for 2012 will not be a problem as long as the prediction error stays constant in the counterfactual scenarios.

Table 2: Out-of-sample validation

\begin{tabular}{|c|c|c|c|c|c|}
\hline \multirow{2}{*}{$\begin{array}{l}\text { Estimation } \\
\text { period }\end{array}$} & \multirow{2}{*}{$\begin{array}{l}\text { Prediction } \\
\text { period }\end{array}$} & \multicolumn{2}{|c|}{ Participation rate } & \multicolumn{2}{|c|}{ Birth rate } \\
\hline & & Data & Model & Data & Model \\
\hline $2005-2010$ & $2005-2010$ & $72.9 \%$ & $72.9 \%$ & $5.6 \%$ & $5.6 \%$ \\
\hline 2005-2006 & $2007-2010$ & $74.8 \%$ & $69.1 \%$ & $5.7 \%$ & $11.1 \%$ \\
\hline $2005-2007$ & $2008-2010$ & $75.9 \%$ & $73.9 \%$ & $5.9 \%$ & $6.4 \%$ \\
\hline $2005-2008$ & 2009-2010 & $76.5 \%$ & $75.2 \%$ & $6.6 \%$ & $5.8 \%$ \\
\hline 2005-2009 & 2010 & $76.8 \%$ & $76.2 \%$ & $6.3 \%$ & $5.5 \%$ \\
\hline
\end{tabular}

Source: Own calculations based on SOEP 2005-2010. N=8329 for 2641 unique households. Birth rate $=$ number of births divided by the number of women aged 23-45. Example: When we estimate the model on data for 2005-2007 and use the parameters to predict fertility and female employment in 2009-2010, we obtain predictions of $75.2 \%$ (participation rate) and $5.8 \%$ (birth rate). The observed values for the 2009-2010 period are $76.5 \%$ and $6.6 \%$, respectively.

\section{$5 \quad$ Policy Experiments}

\subsection{Parental leave benefits}

In 2007, Germany reformed its system of parental leave benefits. The previous meanstested child-rearing benefit (Erziehungsgeld) was replaced by Elterngeld, which depends on (individual) earnings in the year before childbirth. In most cases, the replacement rate is $67 \%$. The benefit is capped at 1800 euros per month, but nevertheless represents a substantial transfer, especially compared to the previous child-rearing benefit. To receive 
the benefit, at least one of the parents has to reduce working hours below the threshold of 30 hours per week. The benefit is paid for twelve months. If both partners reduce their working time, the benefit can be extended to 14 months. We neglect this possibility here as we assume that the labour supply of the male partner is exogenous.

We simulate a policy experiment in which we replace the actual parental leave benefits (Elterngeld) in the 2012 tax-transfer system by the pre-2007 Erziehungsgeld rules. We assume the variant of the Erziehungsgeld in which households receive a maximum of 300 euros for up to 24 months. Alternatively, households could receive 450 euros during 12 months only, but this variant was less popular. ${ }^{13}$ Recall that our model captures the incentives twelve months after birth, so we abstract from the difference in entitlement duration and focus on the effect of the level of benefits and their design (replacement of individual net earnings versus strict means testing at the household level).

We keep the remaining rules of the 2012 tax-transfer-system in place. The simulation takes the interactions within the system into account. Accordingly, a change in the level of parental leave benefits does not lead to a one-to-one change in disposable income as other transfers (e.g., social assistance) or income tax payments will be affected by the change.

Table 3 reports main results from the simulation. We find that a return to the pre-2007 rules of parental leave benefits would have reduced the number of births in 2012 by about 24000. With about 650000 births in Germany in 2012, this corresponds to around $4 \%$ of actual births. The difference is statistically significant at the $10 \%$ level.

The order of magnitude of the effect is quite close to the quasi-experimental study by Raute (2014). Based on Vital Statistics, she documents an increase in birth rates of $4 \%$ nine months after the reform was passed. Moreover, in difference-in-differences and IV estimates based on administrative pension data she finds that for a difference of 1000 euros in total benefits, the probability to give birth is higher by $1.2 \%$ in each of the three years

\footnotetext{
${ }^{13}$ In 2003 , for instance, $88 \%$ of parents chose to receive parental leave benefits for 24 months (cf. Fendrich et al., 2005).
} 
Table 3: Main results: 2007 vs. 2012 rules of parental leave benefits

\begin{tabular}{|c|c|c|c|}
\hline & \multirow[b]{2}{*}{$\begin{array}{r}\text { Fertility } \\
\text { (in } 1000 \text { births) }\end{array}$} & \multicolumn{2}{|c|}{ Employment } \\
\hline & & Participation rate & $\begin{array}{r}\text { Full-time equivalents } \\
\text { (in 1000) }\end{array}$ \\
\hline Total & $-23.9^{*}(14.3)$ & $0.48(0.39)$ & $16.5(12.1)$ \\
\hline $\begin{array}{l}\text { By household income } \\
\text { 1st quartile } \\
\text { 2nd quartile } \\
\text { 3rd quartile } \\
\text { 4th quartile }\end{array}$ & $\begin{array}{r}0.2(0.5) \\
-1.2(1.4) \\
-6.5^{* * *}(2.2) \\
-16.4(13.7)\end{array}$ & $\begin{array}{l}0.02(0.03) \\
0.08(0.11) \\
0.17(0.16) \\
1.79(1.69)\end{array}$ & $\begin{array}{r}0.4^{* *}(0.2) \\
1.2(1.0) \\
1.9(1.3) \\
12.9(11.9)\end{array}$ \\
\hline $\begin{array}{l}\text { By number of children } \\
\text { Without children } \\
\text { One child } \\
\text { Two children } \\
\text { More than two children }\end{array}$ & $\begin{array}{r}-17.1(14.0) \\
-4.1^{* *}(1.8) \\
-2.2(2.1) \\
-0.6(0.9)\end{array}$ & $\begin{array}{r}1.70(1.62) \\
0.19(0.15) \\
0.06(0.11) \\
-0.02(0.10)\end{array}$ & $\begin{array}{r}14.1(12.0) \\
1.7^{*}(0.9) \\
0.7(1.1) \\
0.0(0.2)\end{array}$ \\
\hline
\end{tabular}

Source: Own calculations based on SOEP 2009-2011. N=1059 households. The table shows results from a counterfactual policy experiment in which the 2012 rules of the parental leave benefits (Elterngeld) are replaced by the pre-2007 rules (Erziehungsgeld). One full-time equivalent corresponds to 40 hours per week. Bootstrapped standard errors (100 runs) in parentheses. $* * * \mathrm{p}<0.01, * * \mathrm{p}<0.05$, $* \mathrm{p}<0.1$

after the 2007 reform. As she reports average pre-reform payments in 2006 of about 4000 euros and average post-reform benefits of about 7000 euros, her main estimate is very similar to the prediction from our structural model.

As can be expected, the reduction in the number of births goes hand in hand with an increase in female labour supply. The model predicts that by returning to the pre2007 rules, the labour supply of women would have been higher by about 17000 fulltime equivalents, where one full-time equivalent corresponds to 40 hours per week. The participation rate would have been higher by 0.48 . To put this into perspective, the female labour force participation rate in our estimation period 2005-2010 is $73 \%$ (cf. Table A.3 in the Appendix). The effects on female labour supply are not statistically significant at conventional levels, however.

As the simulations are based on micro data, we can go beyond the average response and study the reactions for different subgroups. Table 3 shows that the fertility reaction is mainly driven by households in the two highest quartiles of the income distribution. This 
also holds when the change is not measured in absolute numbers as in the table, but as a percentage change in the status quo birth rates. Note, however, that only the change for the 3rd quartile is statistically significant. Finding the strongest negative fertility reaction among households with high income is in line with the incentives set by the reform: while the current benefit replaces individual earnings, the pre-2007 system was flat and meanstested. A hypothetical return to this system should then reduce fertility incentives for high-income women, and the model predicts that the difference in the number of births in 2012 is about 6500 for the third and about 16400 for the fourth quartile. ${ }^{14}$

The table also shows that the strongest fertility effect occurs at the extensive margin. The model predicts that a return to the pre-2007 system would reduce first births in 2012 by about 17000 , while the reaction for second or higher-order births is much smaller. ${ }^{15}$ Again, the pattern holds not only for the absolute changes reported in the table, but also for birth rates, i.e. for the changes divided by the baseline number of births in 2012 . That the strongest reaction occurs at the extensive margin is quite plausible: women who do not have any children tend to work full-time, so for them the difference between the flat, means-tested benefit pre-2007 and the new earnings-dependent benefits scheme is greatest. ${ }^{16}$ Note, however, that in our relatively small simulation sample of about 1000 households, only one of the four coefficients is statistically significant at conventional

\footnotetext{
${ }^{14}$ The finding that the effect is strongest for the upper half of the income distribution is consistent with the quasi-experimental study by Raute (2014). She finds some evidence that although the new parental leave benefit increases continuously with pre-birth earnings, the fertility effect appears to reach a plateau at a net income of about 13500 euros per year. The present structural model does not capture this kink (unless one is willing to accept the lack of statistical significance in the fourth quartile as evidence consistent with it). Note, however, that the income measures are not directly comparable: while Raute (2014) measures individual net earnings, the present paper distinguishes the quartiles based on disposable household income.

${ }^{15}$ Note that we classify couples by the number of children at the beginning of each choice situation. So the reduction in the number of births for childless couples refers to the 17000 (first) births that took place in the baseline scenario but, according to our simulations, would not have occurred in the counterfactual scenario.

${ }^{16}$ In her quasi-experimental study, Raute (2014) also finds that the 2007 reform of parental leave benefits most strongly affected the probability of a first birth. Likewise, Bujard and Passet (2013) and Cygan-Rehm (2013) do not find that the reform had a strong impact on higher-order births, although Cygan-Rehm does find some evidence of an effect on the timing of higher-order births (within a time window of 36 months after the previous birth).
} 
levels. ${ }^{17}$

\section{$5.2 \quad$ Alternative specifications}

As noted in Section 2, we follow Haan and Wrohlich (2011) and measure female labour supply twelve months post partum if a woman gave birth, and in March otherwise. When we measure labour supply nine or fifteen months after birth instead, the fertility effects are hardly changed: the simulations predict reductions of 25000 and 28000 births, respectively, instead of the -23900 births in our main specification. For the labour supply reactions the difference is larger, especially at the extensive margin. When labour supply is measured nine or fiveteen months after birth, a return to the pre-2007 parental leave benefits is predicted to increase the participation rate of women in couples by 0.12 and 0.08 percentage points, while the corresponding value is 0.48 percentage points in our main specification. However, these results are still within the $95 \%$ confidence interval of the main estimate.

The main specification compares the current system of parental leave benefits with the pre-2007 rules. We assume that under the pre-2007 rules households would be entitled to a flat benefit of 300 euros per month, which was the amount that households could receive for up to 24 months. There was also a shorter variant in which households received 450 euros for twelve months. When we assume this monthly amount in the comparison, the difference between the pre-2007 and the current benefit amounts becomes smaller. Accordingly, we find a reduction of only about 13000 births in 2012, as opposed to the 24000 in our main specification. The labour supply reactions are also smaller: the participation rate is predicted to increase by 0.28 percentage points, while total labour supply is higher by 12000 full-time equivalents.

Finally, our simulations predict that completely abolishing parental leave benefits would

\footnotetext{
${ }^{17}$ The same holds for the labour supply reactions. In terms of the point estimates, these are the mirror images of the fertility effects. The subgroups with the strongest negative fertility reactions show the strongest positive labour supply effects.
} 
have reduced births by 46000 in 2012 .

\subsection{Comparison with other family policy measures}

Table 4 shows results for other important family policy measures. ${ }^{18}$ Each row of the table is from a separate experiment in which we switch off the indicated measure and keep the remaining rules of the 2012 tax-transfer-system in place.

In 2012, child benefits in Germany amounted to 184 euros per month for the first two children, 190 euros for the third child and 215 euros for additional children. Alternatively, households can deduct a tax allowance of 7008 euros per child from their annual taxable income. Child benefits and child tax allowance last for up to 25 years (and even longer in a few exceptional cases that we neglect here, such as when the child is handicapped).

The simulations predict that without these measures, there would have been 21000 fewer births in 2012. The difference is statistically significant and corresponds to about $3 \%$ of all births actually observed in 2012. Women are predicted to work more, but the effects on the participation rate and the number of full-time equivalents are not significant. Given that child benefits are close to a lump-sum transfer and therefore affect employment mainly through an income effect, finding small labour supply reactions is not surprising.

For income tax splitting, the mechanisms are opposite: while the measure is not directly related to the number of children a couple has, the splitting formula equalizes marginal tax rates of both spouses and therefore has an adverse effect on the labour supply of the secondary earner (typically the woman). ${ }^{19}$ The model predicts that by moving to

\footnotetext{
${ }^{18}$ We have also simulated the labour supply and fertility effects of a number of smaller family policy measures (tax credit for single parents, tax deduction of childcare costs, reduced contribution rate for long-term care insurance for persons with children, child benefits supplement (Kinderzuschlag), childrelated components of social assistance ( $A L G I I)$ and housing benefits, advance payment child alimony (Unterhaltsvorschuss)), but found their fertility effects to be close to zero.

${ }^{19}$ In Germany, married couples can file a joint declaration. Income tax $T$ is calculated as $T=$ $2 t\left(\frac{Y_{M}+Y_{F}}{2}\right)$, where $Y_{M}$ and $Y_{F}$ is taxable income of the spouses, and $t$ is the income tax function. As the income tax system is progressive, the couple as a whole benefits financially. However, for the partner with the lower taxable income (typically the woman), the measure can create strong disincentives to take up employment beyond the threshold of 400 euros per month; below this threshold, earnings are exempt from income tax and employee's social security contributions.
} 
Table 4: Results for other family policy measures

\begin{tabular}{lrrr}
\hline & & \multicolumn{2}{c}{ Employment } \\
\cline { 3 - 4 } & Fertility & Participation rate & $\begin{array}{r}\text { Full-time equivalents } \\
\text { (in 1000) }\end{array}$ \\
\hline Child benefits & $-21^{* * *}(10)$ & $0.13(0.25)$ & $5(7)$ \\
Income tax splitting & $-4(14)$ & $1.23^{* * *}(0.41)$ & $37^{* * *}(12)$ \\
Subsidized childcare & $38^{* *}(19)$ & $-4.23^{* * *}(0.85)$ & $-75^{* * *}(15)$
\end{tabular}

Source: Own calculations based on SOEP 2009-2011. N=1059 households. The simulations are based on the tax-transfer system of 2012. One full-time equivalent corresponds to 40 hours per week. Bootstrapped standard errors (100 runs) in parentheses. ${ }^{* * *} \mathrm{p}<0.01,{ }^{* *} \mathrm{p}<0.05,{ }^{*} \mathrm{p}<0.1$

individual taxation, the number of births in 2012 would have been essentially unchanged, while the participation rate of women in couples would have been higher by 1.23 percentage points. Including also the reactions at the intensive margin, the total labour supply effect corresponds to 37000 full-time equivalents. Note that the table shows the effect for all women in couples. Since some of the women are unmarried, income tax splitting is not directly relevant for them. The effect reported here is therefore smaller than the labour supply effect for married women. Finally, it is important to bear in mind that the model takes the hourly wage offers and the marital status in the choice situation as well as the employment state in the previous period as given. Since these are influenced by the effects of income tax splitting in previous periods, the long-run effect of the measure will be somewhat higher.

Parental fees for public childcare are heavily subsidized in most countries. In Germany, they cover only around $14 \%$ of actual costs (Schilling, 2008). We simulate a policy experiment in which we assume that parents have to bear the full cost of public childcare through their parental fees. Even more so perhaps than for the other three measures, this is a radical departure from the status quo. The results - which rest on the assumption that the parameters of the utility function, the hourly wage offers and the other household and individual characteristics remain constant despite this massive change in incentives - should therefore be interpreted carefully. Note also that we do not take gen- 
eral equilibrium effects into account. Among other things, this means that parents have to pay higher fees, but do not benefit from any tax reductions.

As childcare becomes much more expensive, many mothers decide to work less and to look after their children themselves. The model predicts that the increase in parental fees for childcare to a level that covers full costs leads to a decrease in the participation rate by 4.23 percentage points, and to 75000 fewer full-time equivalents. Note again that this is the reaction for all women aged $23-45$ and living in a couple. This includes women who currently do not have children. For women who already have children, the reaction is stronger. The biggest absolute reduction in the participation rate $(-7.15$ percentage points, not reported in the table) is found for women with two children. For women with more than two children, participation goes down by 4.24 percentage points.

The reduction in female labour supply induced by the high childcare costs has a surprising side effect in the model: some of the women who already have children below the age of 6 and who withdraw from the labour market decide to have an additional child. The mechanism at work here is that the opportunity cost of another child is in fact very low now for women who are already mothers and who prefer to stay at home instead of paying the prohibitively high cost of childcare for their older children. As a result, the model predicts that in the counterfactual scenario in which childcare subsidies are abolished, the number of births in 2012 would have been higher by 38000 . This effect is driven by women with one previous child (16000 additional births) or two previous children (plus 18000 births). Women without any children are affected less as they are not hit by the cost increase for older children. Women with more than two children are also less affected as most of them work few hours already in the status quo.

However, we consider the positive fertility effects that result from making childcare more expensive to be an artifact of the myopic model. In the model, women realize that the increase in childcare costs actually lowers the opportunity cost of another child in the first year after birth, where external childcare is empirically not relevant in Germany anyway. 
In contrast, the model assumes that women do not anticipate that the opportunity cost for the additional child will eventually be much higher now that external childcare has become prohibitively expensive for many women.

\subsection{Variation in the level of parental leave benefits}

Our simulations predict that abolishing parental leave benefits would have reduced births by 46000 in 2012, while switching off child benefits would have led to a reduction of 21000 births. Replacing income tax splitting by individual taxation has almost no effect on fertility, and making parents pay the true cost of public childcare through parental fees is predicted to actually increase fertility. When relating these effects to the fiscal cost, parental leave benefits come out as the clear winner in terms of fiscal efficiency. ${ }^{20}$ However, this comparison is to be taken with a grain of salt as our short-run model is ill-suited for an evaluation of measures that last for a long time (child benefits, income tax splitting) or that set in beyond the one-year horizon assumed in the model (childcare). We therefore refrain from simulations in which we reduce spending on one measure while increasing spending on another measure - such budget-neutral reforms would be interesting from a public policy standpoint, but should be carried out in a more elaborate (life-cycle) model that does better justice to all four family policy measures.

In the present paper, we therefore focus on a single measure. We use our structural model for a series of hypothetical reforms to the current system of parental leave benefits in which we simulate the entitlements according to the status quo rules of 2012 and then multiply them by a factor ranging from 0 to 2 , with a stepsize of 0.1 . At one extreme, parental leave benefits are thus abolished; at the other extreme, the entitlement is doubled. Note that this includes a doubling of the upper limit of 1800 euros per month,

\footnotetext{
${ }^{20}$ Spending on child benefits and child tax allowance amounts to more than 30 billion euros, and income tax splitting costs slightly more than 20 billion euros. In 2008, the precise values were 33.4 and 20.7 billion euros, respectively (BMFSFJ, 2008). Spending on parental leave benefits was 4.6 billion euros in 2010 (BMAS, 2010), while public childcare subsidies totalled 11.1 billion euros (Schilling, 2008). While the values for 2012 may differ slightly, the orders of magnitude and the ranking stay the same.
} 
Figure 1: Fiscal costs of varying the number of births through the generosity of parental leave benefits

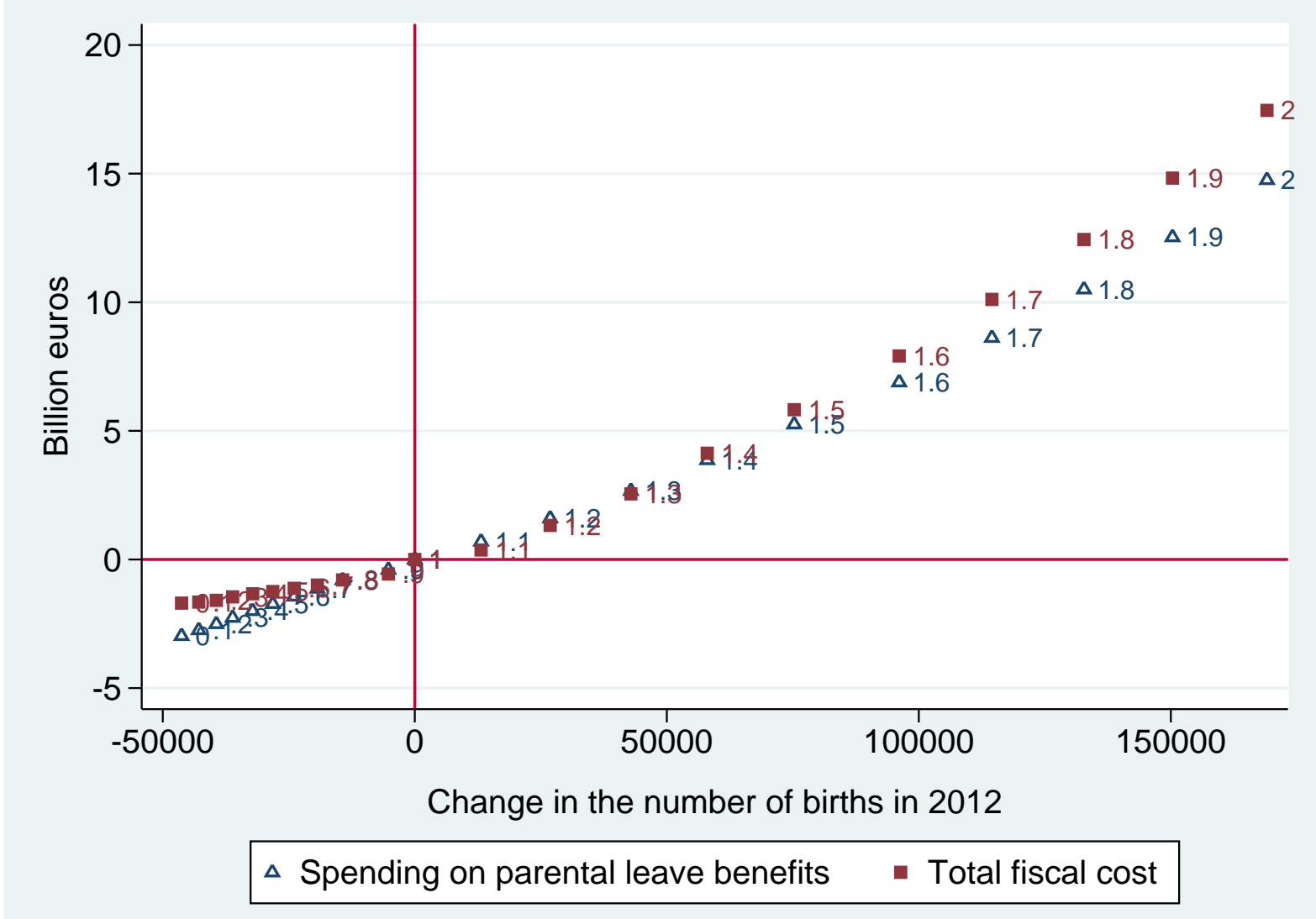

Source: Own calculations based on SOEP 2009-2011. N=1059 households. The simulations are based on the tax-transfer system of 2012. The label next to the marker symbols shows the factor by which the status quo level of parental leave benefits is scaled in a particular scenario.

so the maximum monthly amount is now 3600 euros.

What increase in the number of births can be achieved through the additional fiscal spending? Figure 1 traces out the menu from which, according to the simulations, policy makers can choose. The model predicts that if the level of parental leave benefits had been doubled in 2012, there would have been about 170000 additional births. With about 650000 actual births in that year, this would have been a substantial increase of about a quarter.

However, this increase would have come at a substantial cost. Direct spending on parental leave benefits alone would have been higher by 14.8 billion euros (taking into account the behavioural adjustments). For comparison, actual spending in 2010 was about 4.6 
billion euros (BMAS, 2010). The total fiscal cost would have been even higher at about 17.5 billion euros. This number includes not only the direct spending on parental leave benefits, but also the additional effects that arise from the interactions with income tax payments, social security contributions and transfer receipt. The main driving forces are the increase in child benefits that results from the increase in fertility, as well as a reduction in income tax payments and social security contributions. The latter is a consequence of the reduction in female labour supply that is associated with the greater number of births. ${ }^{21}$

If, on the other hand, parental leave benefits had been zero in 2012, there would have been 46000 fewer births (7\% of actual births). Direct savings would have amounted to 3.0 billion euros. $^{22}$ In contrast, net fiscal savings (i.e., taking into account interactions within the system of taxes and transfers) would have been only around 1.7 billion euros because for low-income households a cut in parental leave benefits is in some cases entirely compensated by a rise in social assistance payments.

\section{Conclusion}

This paper has studied the effects of a number of family policy measures on fertility and female labour supply. Despite the importance of the question there is still little evidence on these effects. Using data from the German Socio-economic Panel (SOEP) and detailed information on childcare costs from a recent SOEP extension, we have estimated a discrete choice model that takes both state dependence and unobserved heterogeneity into account. The estimation exploits the substantial variation in incentives across time and across households that was introduced by the 2007 reform of parental leave benefits

\footnotetext{
${ }^{21}$ While parental leave benefits are not directly taxable in Germany, they affect the tax rate that has to be paid on the taxable income (Progressionsvorbehalt). As a result, a change in parental leave benefits also affects income tax payments without any change in behaviour. This automatic effect is much smaller than the effect due to the behavioural adjustment, however.

${ }^{22}$ The simulation model is based on a sample of households that fulfill certain criteria with respect to the age of the woman and her employment status (cf. Section 3). As a result, simulated spending on parental leave benefits is lower than the official figure of about 4.6 billion euros.
} 
in Germany.

We find that the reform increased the number of births in 2012 by about $4 \%$, a number which is very close to recent quasi-experimental evidence. Our simulations also suggest that in relation to fiscal cost, parental leave benefits are more efficient in setting fertility incentives than child benefits, which are less targeted towards the crucial period right after childbirth.

In an additional set of policy experiments, we have varied the generosity of parental leave benefits while keeping all other rules of the tax-transfer system in place. The model predicts that by doubling the level of benefits, there could have been 150000 additional births in 2012, roughly a quarter of actual births in that year. This increase would have cost about 17.5 billion euros according to the simulations. We show that it is important to use a comprehensive measure of fiscal costs, which takes into account the reactions of income tax revenue, social security contributions and the interactions with other transfers. All results should be considered as approximative, however, as the model abstracts from a number of considerations that might turn out to be important. First and foremost, the model assumes that households make their decisions based exclusively on the incentives one year ahead. This myopic model underestimates the effect of measures that only become relevant after age 1 (subsidized childcare) or that last for a long period of time (child benefits, income tax splitting). We expect that a dynamic programming model with forward-looking behaviour would lead to a more plausible ranking of the measures with respect to effect strength. Importantly, a life-cycle model would also allow making the crucial distinction between effects on completed fertility and mere timing effects. For instance, it is quite likely that the 150000 additional births in 2012 that are predicted to result from making parental leave benefits twice as generous reflect to a large extent pure timing effects.

A second shortcoming of the present model is its partial equilibrium nature. Some of the counterfactual policy experiments that we conducted have substantial fiscal implications, 
and it would be interesting to study to what extent the results still hold when imposing a government budget constraint or allowing for general equilibrium effects on the labour market.

\section{References}

Adda, J., C. Dustmann, and K. Stevens (2011). The career costs of children. IZA Discussion Paper 6201, Bonn.

Azmat, G. and L. González (2010). Targeting fertility and female participation through the income tax. Labour Economics 17(3), 487-502.

Bergemann, A. and R. T. Riphahn (2011a). Female labour supply and parental leave benefits: the causal effect of paying higher transfers for a short period of time. Applied Economics Letters 18(1), 17-20.

Bergemann, A. and R. T. Riphahn (2011b). The introduction of a short-term earningsrelated parental leave benefit system and differential effects on employment intentions. Schmollers Jahrbuch - Journal of Applied Social Sciences Studies 131(2), 315-325.

Bick, A. (2013). The quantitative role of child care for female labor force participation and fertility. Arizona State University.

BMAS (2010). Sozialbudget 2010. Berlin.

BMFSFJ (2008). Familienbezogene Leistungen und Massnahmen des Staates im Jahr 2008. Berlin.

Bonin, H. and H. Schneider (2006). Analytical prediction of transition probabilities in the conditional logit model. Economics Letters 90, 102-107.

Brewer, M., A. Radcliffe, and S. Smith (2012). Does welfare reform affect fertility? Evidence from the UK. Journal of Population Economics 25, 245-266. 
Bujard, M. and J. Passet (2013). Wirkungen des Elterngelds auf Einkommen und Fertilität. Zeitschrift für Familienforschung 25(2), 212-237.

Cohen, A., R. Dehejia, and D. Romanov (2013). Financial incentives and fertility. Review of Economics and Statistics 95(1), 1-20.

Cygan-Rehm, K. (2013). Parental leave benefit and differential fertility responses: Evidence from a German reform. BGPE Discussion Paper No. 142, Erlangen-Nuremberg.

Cygan-Rehm, K. (2014). Wirkungen des Elterngeldes auf die Fertilität - zum Stand der Kenntnis. Vierteljahrshefte zur Wirtschaftsforschung 83(1), 145-162.

Domeij, D. and P. Klein (2013). Should day care be subsidized? The Review of Economic Studies 80(2), 568-595.

Dustmann, C. and U. Schönberg (2012). Expansions in maternity leave coverage and children's long-term outcomes. American Economic Journal: Applied Economics 4(3), $190-224$.

Fehr, H. and D. Ujhelyiova (2012). Fertility, female labor supply and family policy. German Economic Review 14(2), 138-165.

Fendrich, S., J. Fischer, and M. Schilling (2005). Erziehungsgeld und Elternzeit - Bericht des Jahres 2003. Dortmunder Arbeitsstelle Kinder- und Jugendhilfestatistik.

Geisler, E. and M. Kreyenfeld (2012). How policy matters: Germany's parental leave benefit reform and fathers' behavior 1999-2009. MPIDR Working Paper No. 2012-021, Max Planck Institute for Demographic Research, Rostock.

González, L. (2013). The effect of a universal child benefit on conceptions, abortions, and early maternal labor supply. American Economic Journal: Economic Policy 5(3), $160-188$

Haan, P. and K. Wrohlich (2011). Can child care policy encourage employment and fertility? Evidence from a structural model. Labour Economics 18(4), 498-512. 
Heckman, J. (1979). Sample selection bias as a specification error. Econometrica 47 , $153-61$.

Kluve, J. and S. Schmitz (2014). Social norms and mothers' labor market attachment: The medium-run effects of parental benefits. IZA Discussion Paper 8115, Bonn.

Kluve, J. and M. Tamm (2013). Parental leave regulations, mothers' labor force attachment and fathers' childcare involvement: evidence from a natural experiment. Journal of Population Economics 26, 983-1005.

Lalive, R., A. Schlosser, A. Steinhauer, and J. Zweimüller (2014). Parental leave and mothers' careers: The relative importance of job protection and cash benefits. The Review of Economic Studies 81(1), 219-265.

Lalive, R. and J. Zweimüller (2009). Does parental leave affect fertility and return-towork? Evidence from two natural experiments. Quarterly Journal of Economics 24(3), $1363-1402$.

Laroque, G. and B. Salanié (2013). Identifying the response of fertility to financial incentives. Journal of Applied Econometrics, forthcoming.

Milligan, K. (2005). Subsidizing the stork: new evidence on tax incentives and fertility. Review of Economics and Statistics 87(3), 539-55.

Müller, K.-U., C. Spieß, C. Tsiasioti, K. Wrohlich, E. Bügelmayer, L. Haywood, F. Peter, M. Ringmann, and S. Witzke (2013). Evaluation Förderung und Wohlergehen von Kindern. Politikberatung kompakt No. 73, DIW, Berlin.

Neugart, M. and H. Ohlsson (2013). Economic incentives and the timing of births: evidence from the German parental benefit reform of 2007. Journal of Population Economics 26, 87-108.

Raute, A. (2014). Do financial incentives affect fertility? Evidence from a reform in maternity leave benefits. University College London. 
Schilling, M. (2008). Kosten für Kindertageseinrichtungen und Kindertagespflege und ihre Finanzierung. In Deutsches Jugendinstitut (Ed.), Zahlenspiegel 2007 - Kindertagesbetreuung im Spiegel der Statistik. Munich and Dortmund.

Schönberg, U. and J. Ludsteck (2014). Expansions in maternity leave coverage and mothers' labor market outcomes after childbirth. Journal of Labor Economics, forthcoming.

Tamm, M. (2013). The impact of a large parental leave benefit reform on the timing of birth around the day of implementation. Oxford Bulletin of Economics and Statistics $75(4), 585-601$.

Thévenon, O. and A. Solaz (2013). Labour market effects of parental leave policies in OECD countries. Social, Employment and Migration Working Papers No. 141, OECD, Paris.

Wagner, G. G., J. R. Frick, and J. Schupp (2007). The German Socio-Economic Panel Study (SOEP): Scope, evolution and enhancements. Schmollers Jahrbuch - Journal of Applied Social Sciences Studies 127(1), 139-169.

Wooldridge, J. (2005). Simple solutions to the initial conditions problem in dynamic, nonlinear panel data models with unobserved heterogeneity. Journal of Applied Econometrics $20(1), 39-54$.

Wrohlich, K., E. Berger, J. Geyer, P. Haan, D. Sengül, C. Spieß, and A. Thiemann (2012). Elterngeld Monitor. Politikberatung kompakt No. 61, DIW, Berlin. 


\section{A Appendix}

\section{A.1 Simulation of childcare costs and disposable income}

Figure A.1: Disposable household income by earnings of the male partner

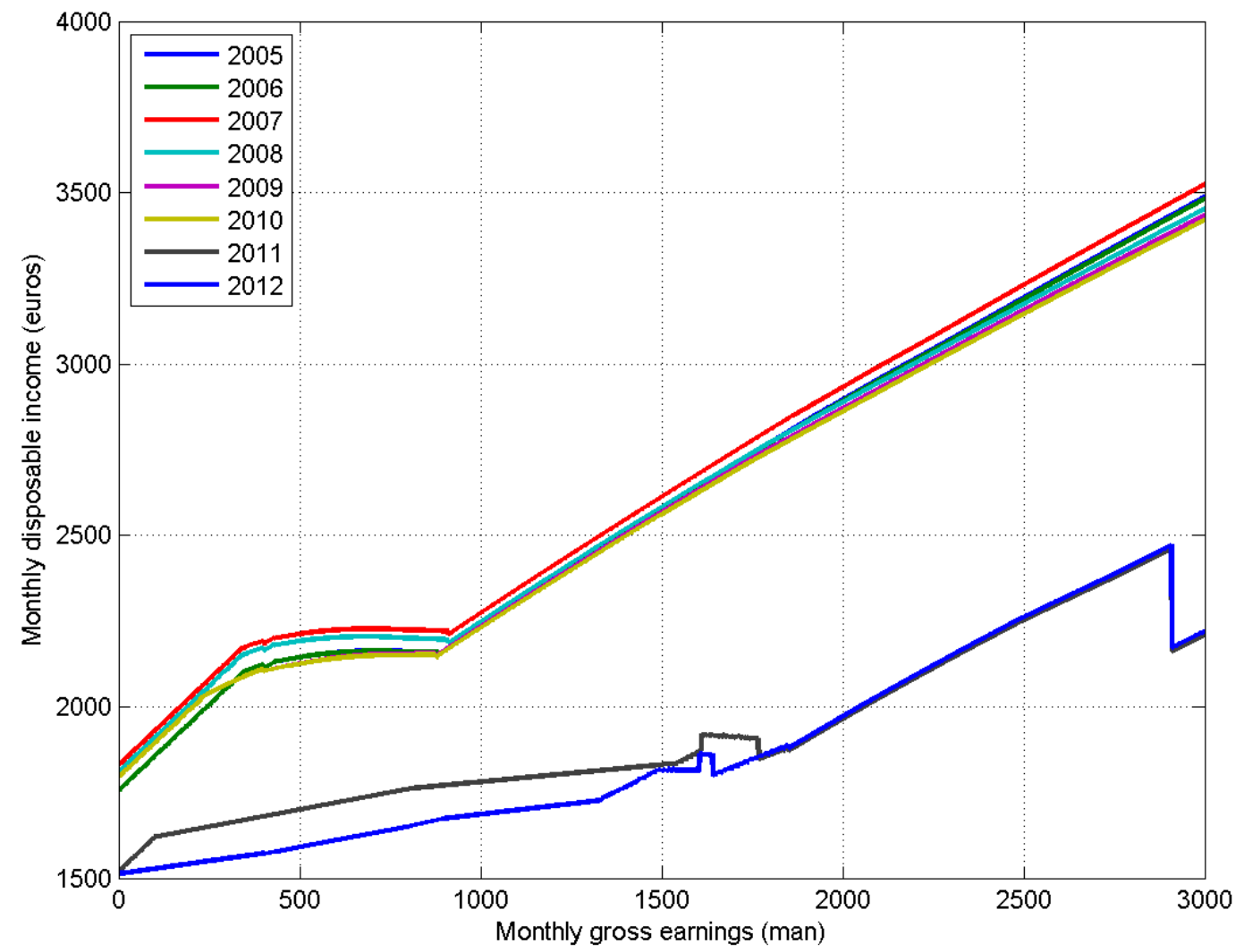

Source: Own calculations. Married couple, one child aged 12 months. Costs for rent and heating: 393 euros per month. The woman is assumed to be not employed. Her earnings in the previous year (relevant for the calculation of parental leave benefits) are set to 2000 euros per month. 
Figure A.2: Disposable household income, couples with and without children

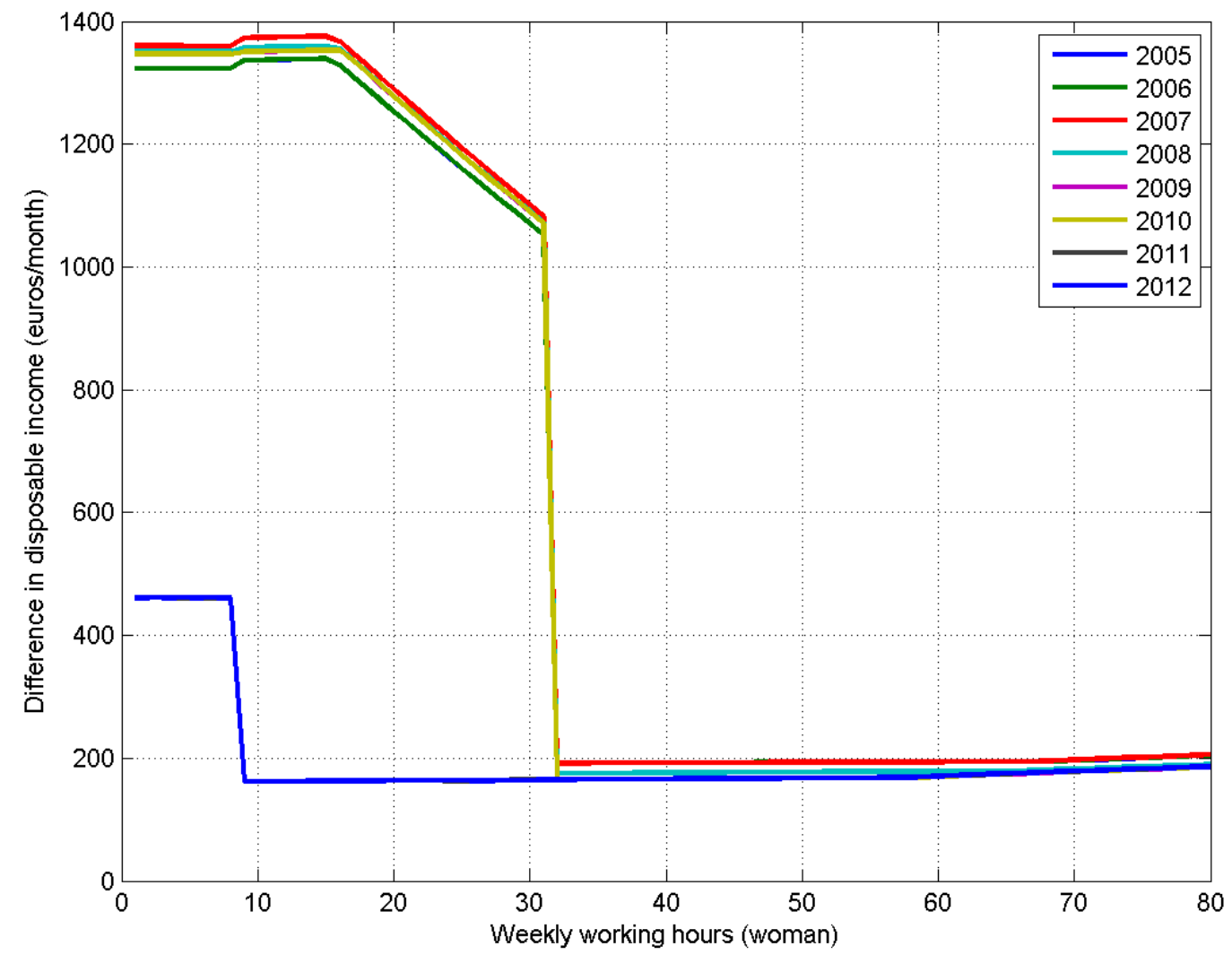

Source: Own calculations. Two married couples, with one child (aged 12 months) and without child. The vertical axis shows the difference in monthyl disposable income between the two households. Costs for rent and heating: 334 euros (no child) and 393 euros (one child) per month. The woman's earnings in the previous year (relevant for the calculation of parental leave benefits) are set to 2000 euros per month. The man is assumed to work 40 hours per week. The gross hourly wage is assumed to be 16 euros (man) and 12.40 euros (woman). 
Table A.1: Probability of not having access to public childcare

\begin{tabular}{lcc}
\hline & Age 0-2 & Age 3-6 \\
\hline East & $10.2 \%$ & $2.3 \%$ \\
West & $15.8 \%$ & $4.3 \%$ \\
Total & $14.8 \%$ & $4.0 \%$ \\
\hline
\end{tabular}

Source: Own calculations based on FiD 2010. Children aged 6 or below. $\mathrm{N}=4517$. Households are classified as not having access to public childcare if parents report that their child is not in public childcare because they could not find a place, because the distance would be too great, or because the opening hours do not correspond to their needs.

Table A.2: Parental fees for public childcare: estimation results

\begin{tabular}{lcccc}
\hline & \multicolumn{2}{c}{ Part-time care } & \multicolumn{2}{c}{ Full-time care } \\
\hline Age $<3$ & $56.2^{* * *}$ & $(14.1)$ & $64.8^{* * *}$ & $(5.8)$ \\
Number of children in household & $-21.9^{* * *}$ & $(4.1)$ & $-28.4^{* * *}$ & $(4.4)$ \\
Net household income (1000 euros/month) & $23.2^{* * *}$ & $(3.1)$ & $17.0^{* * *}$ & $(3.8)$ \\
Single parent & $-23.6^{* *}$ & $(9.4)$ & $-32.0^{* * *}$ & $(10.5)$ \\
Intercept & $39.7^{* *}$ & $(16.4)$ & $149.1^{* * *}$ & Yes \\
Dummies for federal state & & Yes & & 906 \\
Number of observations & & 972 & & 171 \\
Of which left-censored & \multicolumn{2}{c}{222} & & 0.03 \\
Pseudo $R^{2}$ & \multicolumn{2}{c}{0.05} & & \\
\hline
\end{tabular}

Source: Own calculations based on FiD 2010. Dependent variable: self-reported parental fees per month. Results from Tobit models. Children aged 6 or below. Asymptotic standard errors (clustered at the household level) in parentheses. ${ }^{* * *} \mathrm{p}<0.01,{ }^{* *} \mathrm{p}<0.05,{ }^{*} \mathrm{p}<0.1$ 


\section{A.2 Summary statistics}

Table A.3: Summary statistics

\begin{tabular}{|c|c|c|c|}
\hline & $\begin{array}{c}\text { House- } \\
\text { hold }\end{array}$ & $\begin{array}{l}\text { Female } \\
\text { partner }\end{array}$ & $\begin{array}{c}\text { Male } \\
\text { partner }\end{array}$ \\
\hline Married & $84 \%$ & - & - \\
\hline East Germany & $22 \%$ & - & - \\
\hline No children & $26 \%$ & - & - \\
\hline One child & $30 \%$ & - & - \\
\hline Two children & $33 \%$ & - & - \\
\hline More than two children & $11 \%$ & - & - \\
\hline Youngest child aged 0-2 & $16 \%$ & - & - \\
\hline Youngest child aged 3-6 & $27 \%$ & - & - \\
\hline Youngest child aged $>6$ & $58 \%$ & - & - \\
\hline Not employed & - & $27 \%$ & $6 \%$ \\
\hline Part-time & - & $41 \%$ & $3 \%$ \\
\hline Full-time & - & $32 \%$ & $87 \%$ \\
\hline Other & - & - & $3 \%$ \\
\hline Wage offer & - & 11.2 & 16.9 \\
\hline Expected childcare costs: Part-time, Age $0-2$ & $196 €$ & - & - \\
\hline Expected childcare costs: Full-time, Age $0-2$ & $311 €$ & - & - \\
\hline Expected childcare costs: Part-time, Age 3-6 & $100 €$ & - & - \\
\hline Expected childcare costs: Full-time, Age 3-6 & $152 €$ & - & - \\
\hline Immigrant & - & $15 \%$ & $15 \%$ \\
\hline Son/daughter of immigrants & - & $5 \%$ & $5 \%$ \\
\hline No vocational training & - & $14 \%$ & $11 \%$ \\
\hline Secondary degree and/or vocational training & - & $67 \%$ & $67 \%$ \\
\hline Tertiary degree & - & $19 \%$ & $22 \%$ \\
\hline Civil servant & - & $5 \%$ & $7 \%$ \\
\hline Worried about financial situation & - & $24 \%$ & $25 \%$ \\
\hline Age & - & 37 & 40 \\
\hline & - & $\begin{array}{l}\text { (SD: } 5.7, \text { Min: } 23, \\
\text { Max: } 45 \text { ) }\end{array}$ & $\begin{array}{l}\text { (SD: } 6.7, \text { Min: } 22, \\
\text { Max: } 71 \text { ) }\end{array}$ \\
\hline \multirow[t]{2}{*}{ Satisfied with health } & - & 7.2 & 7.1 \\
\hline & - & $\begin{array}{l}\text { (SD: 1.9, Min: } 0, \\
\text { Max: 10) }\end{array}$ & $\begin{array}{l}\text { (SD: 1.9, Min: } 0, \\
\text { Max: } 10 \text { ) }\end{array}$ \\
\hline Number of observations & 8329 & 8329 & 8329 \\
\hline Number of households & 2641 & 2641 & 2641 \\
\hline
\end{tabular}

Source: Own calculations based on SOEP 2004-2011. SD: standard deviation. Min: minimum. Max: maximum. See Section 2 for the construction of expected childcare costs. 


\section{A.3 Additional tables and figures}

Table A.4: Wage estimation — Women in West Germany

\begin{tabular}{|c|c|c|}
\hline & Log(hourly wage) & Participation \\
\hline Secondary degree and/or vocational training & $0.16^{* * *}(0.010)$ & $0.42^{* * *}(0.025)$ \\
\hline Tertiary degree & $0.50 * * *(0.013)$ & $0.82 * * *(0.032)$ \\
\hline Experience: full-time (years) & $0.03^{* * *}(0.001)$ & $0.05^{* * *}(0.003)$ \\
\hline Experience: full-time (years) squared & $-0.0004^{* * *}(0.00003)$ & $-0.0002^{* *}(0.0001)$ \\
\hline Experience: part-time (years) & $-0.003^{* *}(0.0015)$ & $0.13^{* * *}(0.004)$ \\
\hline Experience: part-time (years) squared & $0.0002^{* * *}(0.00005)$ & $-0.003^{* * *}(0.0002)$ \\
\hline Total years unemployed & $-0.05^{* * *}(0.002)$ & - \\
\hline Married & $-0.04 * * *(0.008)$ & $-0.48^{* * *}(0.023)$ \\
\hline Civil servant & $0.17^{* * *}(0.011)$ & - \\
\hline Foreign nationality & $-0.11^{* * *}(0.011)$ & $-0.18^{* * *}(0.030)$ \\
\hline Number of children aged $<3$ & - & $-1.04^{* * *}(0.034)$ \\
\hline Number of children aged between 3 and 6 & - & $-0.15^{* * *}(0.021)$ \\
\hline Number of children aged between 7 and 16 & - & $-0.02 * *(0.012)$ \\
\hline Person needing long-term care in household & - & $-0.43^{* * *}(0.067)$ \\
\hline Handicap & - & $-0.54^{* * *}(0.049)$ \\
\hline Capital income at household level (euros/month) & - & $-0.0001^{* *}(0.00004)$ \\
\hline Other revenues at household level (euros/months) & - & $-0.001^{* * *}(0.0001)$ \\
\hline Intercept & $2.17^{* * *}(0.027)$ & $-0.23^{* * *}(0.060)$ \\
\hline Rho & \multicolumn{2}{|c|}{$0.01(0.05)$} \\
\hline Sigma & \multicolumn{2}{|c|}{$0.39(0.002)$} \\
\hline Log-likelihood & \multicolumn{2}{|c|}{-21784.25} \\
\hline Number of observations & \multicolumn{2}{|c|}{27317} \\
\hline
\end{tabular}

Source: Own calculations based on SOEP 2004-2011. In addition to the variables shown here, the models include year dummies and dummies for the federal state. Omitted reference category: left school without a degree. 


\section{Table A.5: Wage estimation — Women in East Germany}

\begin{tabular}{lrr}
\hline & Log(hourly wage) & Participation \\
\hline Secondary degree and/or vocational training & $0.001(0.029)$ & $0.78^{* * *}(0.067)$ \\
Tertiary degree & $0.29^{* * *}(0.032)$ & $1.45^{* * *}(0.075)$ \\
Experience: full-time (years) & $0.01^{* * *}(0.002)$ & $0.02^{* * *}(0.006)$ \\
Experience: full-time (years) squared & $-0.0003^{* * *}(0.00005)$ & $0.0004^{* *}(0.00002)$ \\
Experience: part-time (years) & $-0.01^{* * *}(0.002)$ & $0.10^{* * *}(0.008)$ \\
Experience: part-time (years) squared & $0.0005^{* * *}(0.0001)$ & $-0.003^{* * *}(0.0004)$ \\
Total years unemployed & $-0.07^{* * *}(0.02)$ & $-0.06^{*}(0.038)$ \\
Married & $0.06^{* * *}(0.011)$ & $-1.15^{* * *}(0.063)$ \\
Civil servant & $0.25^{* * *}(0.023)$ & $0.04(0.043)$ \\
Number of children aged $<3$ & - & $0.05^{*}(0.026)$ \\
Number of children aged between 3 and 6 & - & $-0.61^{* * *}(0.114)$ \\
Number of children aged between 7 and 16 & - & $-0.20^{* *}(0.093)$ \\
Person needing long-term care in household & - & $0.001^{* * *}(0.0002)$ \\
Handicap & - & $-0.002^{* * *}(0.0003)$ \\
Capital income at household level (euros/month) & - & $-0.75^{* * *}(0.106)$ \\
Other revenues at household level (euros/months) & $-0.54(0.05)$ & \\
Intercept & $0.40(0.005)$ & \\
Rho & -6449.51 & \\
Sigma & 8373 & \\
Log-likelihood & $2.3^{* * *}(0.045)$ & \\
Number of observations & - & \\
\hline
\end{tabular}

Source: Own calculations based on SOEP 2004-2011. In addition to the variables shown here, the models include year dummies and dummies for the federal state. Omitted reference category: left school without a degree. 
Table A.6: Women — employment conditional on birth in previous year

\begin{tabular}{|c|c|c|c|c|c|c|}
\hline & \multicolumn{3}{|c|}{ No birth in previous year } & \multicolumn{3}{|c|}{ Birth in previous year } \\
\hline & $\begin{array}{c}\text { Not } \\
\text { employed }\end{array}$ & $\begin{array}{l}\text { Part- } \\
\text { time }\end{array}$ & $\begin{array}{l}\text { Full- } \\
\text { time }\end{array}$ & $\begin{array}{c}\text { Not } \\
\text { employed }\end{array}$ & $\begin{array}{l}\text { Part- } \\
\text { time }\end{array}$ & $\begin{array}{l}\text { Full- } \\
\text { time }\end{array}$ \\
\hline East & $17 \%$ & $34 \%$ & $49 \%$ & $73 \%$ & $14 \%$ & $13 \%$ \\
\hline West & $26 \%$ & $45 \%$ & $28 \%$ & $80 \%$ & $16 \%$ & $4 \%$ \\
\hline Already has children & $30 \%$ & $51 \%$ & $19 \%$ & $83 \%$ & $13 \%$ & $5 \%$ \\
\hline No other children & $9 \%$ & $19 \%$ & $72 \%$ & $69 \%$ & $22 \%$ & $9 \%$ \\
\hline Total & $24 \%$ & $43 \%$ & $33 \%$ & $78 \%$ & $16 \%$ & $6 \%$ \\
\hline
\end{tabular}

Source: Own calculations based on SOEP 2004-2011. N=8329 for 2641 unique households. Example: Twelve months after giving birth, $13 \%$ of women in East Germany and $4 \%$ of women in West Germany work full time.

Table A.7: Men — employment conditional on birth in previous year

\begin{tabular}{lcccccccc}
\hline & \multicolumn{3}{c}{ No birth in previous year } & \multicolumn{3}{c}{ Birth in previous year } \\
& $\begin{array}{c}\text { Not } \\
\text { employed }\end{array}$ & $\begin{array}{c}\text { Part- } \\
\text { time }\end{array}$ & $\begin{array}{c}\text { Full- } \\
\text { time }\end{array}$ & Other & $\begin{array}{c}\text { Not } \\
\text { employed }\end{array}$ & $\begin{array}{c}\text { Part- } \\
\text { time }\end{array}$ & $\begin{array}{c}\text { Full- } \\
\text { time }\end{array}$ & Other \\
\hline East & $9 \%$ & $2 \%$ & $84 \%$ & $4 \%$ & $13 \%$ & $4 \%$ & $81 \%$ & $3 \%$ \\
West & $5 \%$ & $4 \%$ & $88 \%$ & $3 \%$ & $6 \%$ & $4 \%$ & $87 \%$ & $2 \%$ \\
Already has children & $5 \%$ & $4 \%$ & $87 \%$ & $4 \%$ & $6 \%$ & $6 \%$ & $88 \%$ & $1 \%$ \\
No other children & $6 \%$ & $3 \%$ & $87 \%$ & $4 \%$ & $9 \%$ & $5 \%$ & $84 \%$ & $2 \%$ \\
Total & $6 \%$ & $3 \%$ & $87 \%$ & $3 \%$ & $8 \%$ & $4 \%$ & $86 \%$ & $2 \%$ \\
\hline
\end{tabular}

Source: Own calculations based on SOEP 2004-2011. N=8329 for 2641 unique households. Other: education, military/civilian service, pensioners. Example: Twelve months after a child is born, $81 \%$ of men in East Germany and $87 \%$ of men in West Germany work full time. 
Without random effects With random effects

\begin{tabular}{|c|c|c|}
\hline $\log \mathrm{C}$ & $\begin{array}{r}8.11^{* * *} \\
(3.09)\end{array}$ & $\begin{array}{r}8.45^{* * *} \\
(2.59)\end{array}$ \\
\hline $\mathrm{Lf}$ & $\begin{array}{r}6.03^{\text {*** }} \\
(0.35)\end{array}$ & $\begin{array}{r}6.08^{* * *} \\
(0.32)\end{array}$ \\
\hline $\mathrm{Lf} \times \mathrm{Lf}$ & $\begin{array}{r}-0.55^{* * *} \\
(0.01)\end{array}$ & $\begin{array}{r}-0.55^{* * *} \\
(0.01)\end{array}$ \\
\hline Birth & $\begin{array}{r}-1.76 \\
(2.13)\end{array}$ & $\begin{array}{c}-2.38 \\
(2.19)\end{array}$ \\
\hline $\log \mathrm{C} \times$ one child & $\begin{array}{r}-4.04^{* * *} \\
(0.71)\end{array}$ & $\begin{array}{r}-4.51^{* * *} \\
(0.74)\end{array}$ \\
\hline LogC $\times$ two children & $\begin{array}{r}-3.15^{* * *} \\
(0.83)\end{array}$ & $\begin{array}{r}-3.71^{* * *} \\
(0.85)\end{array}$ \\
\hline $\log \mathrm{C} \times$ three or more children & $\begin{array}{r}-3.53^{* * *} \\
(1.32)\end{array}$ & $\begin{array}{r}-4.13^{* * *} \\
(1.35)\end{array}$ \\
\hline $\log C \times$ age $($ woman $) \in[23,29]$ & $\begin{array}{l}-1.41 \\
(1.18)\end{array}$ & $\begin{array}{r}-1.00 \\
(0.99)\end{array}$ \\
\hline $\log C \times$ age $($ woman $) \in[30,34]$ & $\begin{array}{c}-0.32 \\
(0.91)\end{array}$ & $\begin{array}{l}-0.01 \\
(0.43)\end{array}$ \\
\hline $\log C \times$ age $($ woman $) \in[35,39]$ & $\begin{array}{r}1.01 \\
(0.78)\end{array}$ & $\begin{array}{l}1.24^{*} \\
(0.69)\end{array}$ \\
\hline LogC $\times$ age $(\operatorname{man})($ years $/ 10)$ & $\begin{array}{r}-1.12^{* *} \\
(0.53)\end{array}$ & $\begin{array}{r}-1.18^{* *} \\
(0.46)\end{array}$ \\
\hline LogC $\times$ immigrant (woman) & $\begin{array}{r}1.25 \\
(0.88)\end{array}$ & $\begin{array}{r}1.28 \\
(0.89)\end{array}$ \\
\hline $\log \mathrm{C} \times 2$ nd generation immigrant (woman) & $\begin{array}{r}1.67 \\
(1.26)\end{array}$ & $\begin{array}{r}1.78 \\
(1.23)\end{array}$ \\
\hline LogC $\times$ East Germany & $\begin{array}{r}-0.98 \\
(0.64)\end{array}$ & $\begin{array}{l}-1.13^{*} \\
(0.65)\end{array}$ \\
\hline LogC $\times$ married & $\begin{array}{r}0.70 \\
(0.75)\end{array}$ & $\begin{array}{r}0.86 \\
(0.77)\end{array}$ \\
\hline $\log \mathrm{C} \times$ neither secondary nor vocational degree (woman) & $\begin{array}{r}2.13^{* *} \\
(1.04)\end{array}$ & $\begin{array}{r}2.33^{* * *} \\
(1.08)\end{array}$ \\
\hline LogC $\times$ neither secondary nor vocational degree $(\operatorname{man})$ & $\begin{array}{r}-1.85^{* *} \\
(0.88)\end{array}$ & $\begin{array}{r}-2.02^{* * *} \\
(0.90)\end{array}$ \\
\hline $\log \mathrm{C} \times$ tertiary degree $($ woman $)$ & $\begin{array}{l}-0.38 \\
(0.67)\end{array}$ & $\begin{array}{c}-0.22 \\
(0.68)\end{array}$ \\
\hline $\log \mathrm{C} \times$ tertiary degree $(\operatorname{man})$ & $\begin{array}{r}0.86 \\
(0.71)\end{array}$ & $\begin{array}{r}1.04 \\
(0.72)\end{array}$ \\
\hline $\log C \times$ civil servant (woman) & $-3.78^{* * *}$ & $-4.12^{* * *}$ \\
\hline
\end{tabular}


Table A.8: (continued)

Without random effects With random effects

\begin{tabular}{|c|c|c|}
\hline & $(1.26)$ & $(1.27)$ \\
\hline \multirow[t]{2}{*}{$\log C \times$ civil servant $(\operatorname{man})$} & 0.93 & 0.76 \\
\hline & $(1.18)$ & $(1.18)$ \\
\hline \multirow[t]{2}{*}{$\log \mathrm{C} \times$ worried about own financial situation (woman) } & 0.44 & 0.32 \\
\hline & $(0.62)$ & $(0.64)$ \\
\hline \multirow[t]{2}{*}{$\log C \times$ size of flat or house (square metres $/ 100$ ) } & 1.47 & 1.66 \\
\hline & $(1.03)$ & $(1.05)$ \\
\hline \multirow[t]{2}{*}{$\log \mathrm{C} \times$ satisfied with health (woman) } & 0.95 & 1.09 \\
\hline & $(1.44)$ & $(0.88)$ \\
\hline \multirow[t]{2}{*}{$\log \mathrm{C} \times \operatorname{Lf}$} & -0.02 & -0.02 \\
\hline & $(0.09)$ & $(0.09)$ \\
\hline \multirow[t]{2}{*}{$\log \mathrm{C} \times$ Birth } & -1.80 & -2.23 \\
\hline & $(1.47)$ & $(1.61)$ \\
\hline \multirow[t]{2}{*}{$\log C \times \log C$} & 0.76 & 0.72 \\
\hline & $(0.52)$ & $(0.53)$ \\
\hline \multirow[t]{2}{*}{$\log C \times \log C \times \log C$} & -0.08 & -0.14 \\
\hline & $(0.50)$ & $(0.56)$ \\
\hline \multirow[t]{2}{*}{$\log C \times \operatorname{Lf} \times \log C$} & 0.03 & 0.08 \\
\hline & $(0.15)$ & $(0.16)$ \\
\hline \multirow[t]{2}{*}{ Lf $\times$ one child } & $-0.34^{* * *}$ & $-0.38^{* * *}$ \\
\hline & $(0.07)$ & $(0.07)$ \\
\hline \multirow[t]{2}{*}{ Lf $\times$ two children } & $-0.36^{* * *}$ & $-0.41^{* * *}$ \\
\hline & $(0.08)$ & $(0.08)$ \\
\hline \multirow[t]{2}{*}{ Lf $\times$ three or more children } & $-0.26^{* *}$ & $-0.31^{* * *}$ \\
\hline & $(0.11)$ & $(0.11)$ \\
\hline \multirow[t]{2}{*}{ Lf $\times$ age $($ woman $) \in[23,29]$} & $-3.00^{* * *}$ & $-3.02^{* * *}$ \\
\hline & $(0.34)$ & $(0.34)$ \\
\hline \multirow[t]{2}{*}{ Lf $\times$ age $($ woman $) \in[30,34]$} & $-1.05^{* * *}$ & $-1.06^{* * *}$ \\
\hline & $(0.27)$ & $(0.25)$ \\
\hline \multirow[t]{2}{*}{ Lf $\times$ age $($ woman $) \in[35,39]$} & -0.13 & -0.11 \\
\hline & $(0.23)$ & $(0.23)$ \\
\hline \multirow[t]{2}{*}{ Lf $\times$ age $(\operatorname{man})($ years $/ 10)$} & $-0.14^{* * *}$ & $-0.15^{* * *}$ \\
\hline & $(0.05)$ & $(0.05)$ \\
\hline \multirow[t]{2}{*}{ Lf $\times$ immigrant (woman) } & 0.10 & 0.10 \\
\hline & $(0.08)$ & $(0.08)$ \\
\hline \multirow[t]{2}{*}{ Lf $\times 2$ nd generation immigrant (woman) } & -0.01 & 0.01 \\
\hline & $(0.11)$ & $(0.11)$ \\
\hline \multirow[t]{2}{*}{ Lf $\times$ East Germany } & $-0.37^{* * *}$ & $-0.38^{* * *}$ \\
\hline & $(0.06)$ & $(0.06)$ \\
\hline
\end{tabular}


Table A.8: (continued)

Without random effects With random effects

\begin{tabular}{|c|c|c|}
\hline Lf $\times$ married & $\begin{array}{r}0.19^{* *} \\
(0.07)\end{array}$ & $\begin{array}{r}0.19^{* *} \\
(0.08)\end{array}$ \\
\hline Lf $\times$ neither secondary nor vocational degree (woman) & $\begin{array}{r}0.24^{* * *} \\
(0.08)\end{array}$ & $\begin{array}{r}0.26^{* * *} \\
(0.08)\end{array}$ \\
\hline Lf $\times$ neither secondary nor vocational degree (man) & $\begin{array}{r}-0.03 \\
(0.08)\end{array}$ & $\begin{array}{r}-0.05 \\
(0.08)\end{array}$ \\
\hline Lf $\times$ tertiary degree $($ woman $)$ & $\begin{array}{r}-0.04 \\
(0.07)\end{array}$ & $\begin{array}{r}-0.02 \\
(0.07)\end{array}$ \\
\hline Lf $\times$ tertiary degree $(\operatorname{man})$ & $\begin{array}{r}0.16^{* *} \\
(0.06)\end{array}$ & $\begin{array}{r}0.17^{* *} \\
(0.07)\end{array}$ \\
\hline Lf $\times$ civil servant (woman) & $\begin{array}{r}-0.54^{* * *} \\
(0.17)\end{array}$ & $\begin{array}{r}-0.57^{* * *} \\
(0.17)\end{array}$ \\
\hline $\mathrm{Lf} \times$ civil servant $(\operatorname{man})$ & $\begin{array}{r}0.22^{* *} \\
(0.11)\end{array}$ & $\begin{array}{l}0.20^{*} \\
(0.11)\end{array}$ \\
\hline Lf $\times$ worried about own financial situation (woman) & $\begin{array}{r}0.09 \\
(0.06)\end{array}$ & $\begin{array}{r}0.07 \\
(0.06)\end{array}$ \\
\hline Lf $\times$ size of flat or house (square metres/100) & $\begin{array}{r}0.13 \\
(0.09)\end{array}$ & $\begin{array}{r}0.14 \\
(0.10)\end{array}$ \\
\hline Lf $\times$ satisfied with health (woman) & $\begin{array}{r}-0.02 \\
(0.13)\end{array}$ & $\begin{array}{r}-0.00 \\
(0.04)\end{array}$ \\
\hline Lf $\times$ Birth & $\begin{array}{r}-2.09^{* * *} \\
(0.54)\end{array}$ & $\begin{array}{r}-2.20^{* * *} \\
(0.55)\end{array}$ \\
\hline Lf $\times$ Lf (previous year) & $\begin{array}{r}0.40^{* * *} \\
(0.01)\end{array}$ & $\begin{array}{r}0.41^{* * *} \\
(0.01)\end{array}$ \\
\hline Lf $\times$ Birth (previous year) & $\begin{array}{r}0.25^{* * *} \\
(0.06)\end{array}$ & $\begin{array}{r}0.24^{* * *} \\
(0.06)\end{array}$ \\
\hline Lf $\times$ Lf (initially observed) & $\begin{array}{r}-0.93^{* * *} \\
(0.03)\end{array}$ & $\begin{array}{r}-0.93^{* * *} \\
(0.03)\end{array}$ \\
\hline Lf $\times$ Birth (initially observed) & $\begin{array}{r}-0.57^{* * *} \\
(0.06)\end{array}$ & $\begin{array}{r}-0.58^{* * *} \\
(0.06)\end{array}$ \\
\hline $\operatorname{Lf} \times \operatorname{Lf} \times$ age $($ woman $) \in[23,29]$ & $\begin{array}{r}0.23^{* * *} \\
(0.03)\end{array}$ & $\begin{array}{r}0.24^{* * *} \\
(0.03)\end{array}$ \\
\hline $\operatorname{Lf} \times \operatorname{Lf} \times$ age $($ woman $) \in[30,34]$ & $\begin{array}{r}0.07^{* * *} \\
(0.02)\end{array}$ & $\begin{array}{r}0.08^{* * *} \\
(0.02)\end{array}$ \\
\hline $\operatorname{Lf} \times \operatorname{Lf} \times$ age $($ woman $) \in[35,39]$ & $\begin{array}{r}0.01 \\
(0.02)\end{array}$ & $\begin{array}{r}0.01 \\
(0.02)\end{array}$ \\
\hline Lf $\times$ Lf $\times$ Birth & $\begin{array}{r}0.27^{* * *} \\
(0.04)\end{array}$ & $\begin{array}{r}0.28^{* * *} \\
(0.04)\end{array}$ \\
\hline Birth $\times$ one child & 0.13 & -0.05 \\
\hline
\end{tabular}


Table A.8: (continued)

Without random effects With random effects

\begin{tabular}{|c|c|c|}
\hline & $(0.22)$ & $(0.24)$ \\
\hline \multirow[t]{2}{*}{ Birth $\times$ two children } & $-1.06^{* * *}$ & $-1.29^{* * *}$ \\
\hline & $(0.31)$ & $(0.34)$ \\
\hline \multirow[t]{2}{*}{ Birth $\times$ three or more children } & -0.42 & -0.66 \\
\hline & $(0.38)$ & $(0.42)$ \\
\hline \multirow[t]{2}{*}{ Birth $\times$ age $($ woman $) \in[23,29]$} & $1.96^{* * *}$ & $2.05^{* * *}$ \\
\hline & $(0.38)$ & $(0.39)$ \\
\hline \multirow[t]{2}{*}{ Birth $\times$ age $($ woman $) \in[30,34]$} & $1.94^{* * *}$ & $2.11^{* * *}$ \\
\hline & $(0.31)$ & $(0.30)$ \\
\hline \multirow[t]{2}{*}{ Birth $\times$ age $($ woman $) \in[35,39]$} & $1.33^{* * *}$ & $1.52^{* * *}$ \\
\hline & $(0.27)$ & $(0.28)$ \\
\hline \multirow[t]{2}{*}{ Birth $\times$ age $(\operatorname{man})($ years $/ 10)$} & $-0.61^{* * *}$ & $-0.72^{* * *}$ \\
\hline & $(0.19)$ & $(0.20)$ \\
\hline \multirow[t]{2}{*}{ Birth $\times$ immigrant (woman) } & $-0.44^{*}$ & -0.43 \\
\hline & $(0.26)$ & $(0.28)$ \\
\hline \multirow[t]{2}{*}{ Birth $\times 2$ nd generation immigrant (woman) } & -0.01 & 0.01 \\
\hline & $(0.34)$ & $(0.33)$ \\
\hline \multirow[t]{2}{*}{ Birth $\times$ East Germany } & $0.48^{* *}$ & $0.52^{* *}$ \\
\hline & $(0.20)$ & $(0.22)$ \\
\hline \multirow[t]{2}{*}{ Birth $\times$ married } & $0.77^{* * *}$ & $0.92^{* * *}$ \\
\hline & $(0.24)$ & $(0.26)$ \\
\hline \multirow[t]{2}{*}{ Birth $\times$ neither secondary nor vocational degree (woman) } & $-0.75^{* *}$ & $-0.91^{* * *}$ \\
\hline & $(0.29)$ & $(0.32)$ \\
\hline \multirow[t]{2}{*}{ Birth $\times$ neither secondary nor vocational degree (man) } & -0.03 & -0.03 \\
\hline & $(0.28)$ & $(0.30)$ \\
\hline \multirow[t]{2}{*}{ Birth $\times$ tertiary degree $($ woman $)$} & $0.78^{* * *}$ & $0.83^{* * *}$ \\
\hline & $(0.20)$ & $(0.23)$ \\
\hline \multirow[t]{2}{*}{ Birth $\times$ tertiary degree $(\operatorname{man})$} & $0.50^{* *}$ & $0.56^{* *}$ \\
\hline & $(0.20)$ & $(0.22)$ \\
\hline \multirow[t]{2}{*}{ Birth $\times$ civil servant (woman) } & -0.65 & $-1.02^{*}$ \\
\hline & $(0.48)$ & $(0.52)$ \\
\hline \multirow[t]{2}{*}{ Birth $\times$ civil servant $(\operatorname{man})$} & 0.42 & 0.46 \\
\hline & $(0.30)$ & $(0.33)$ \\
\hline \multirow[t]{2}{*}{ Birth $\times$ worried about own financial situation (woman) } & $-0.32^{*}$ & -0.31 \\
\hline & $(0.19)$ & $(0.20)$ \\
\hline \multirow[t]{2}{*}{ Birth $\times$ size of flat or house (square metres/100) } & $0.91^{* * *}$ & $1.06^{* * *}$ \\
\hline & $(0.30)$ & $(0.33)$ \\
\hline \multirow[t]{2}{*}{ Birth $\times$ satisfied with health (woman) } & $0.76^{*}$ & $0.74^{*}$ \\
\hline & $(0.44)$ & $(0.39)$ \\
\hline
\end{tabular}


Table A.8: (continued)

Without random effects With random effects

Birth $\times$ two children $\times$ children of same sex

$0.56^{* *}$

$0.53^{*}$

$(0.25)$

$(0.28)$

Birth $\times$ three or more children $\times$ children of same sex

$-0.50$

$-0.58$

$(0.53)$

$(0.60)$

Birth $\times$ Lf (previous year)

$-0.28 * * *$

$-0.25 * * *$

$(0.06)$

Birth $\times$ Birth (previous year)

$-3.04^{* * *}$

$-3.47^{* * *}$

$(0.30)$

Birth $\times$ Lf (initially observed)

$1.42^{* * *}$

$1.42^{* * *}$

Birth $\times$ Birth (initially observed)

$3.16 * * *$ $3.79 * * *$

Birth $\times$ mass point 1

$\pi_{1}$

Log-likelihood

$-5397.0$

$-5387.2$

Observations

49974

49974

Source: Own calculations based on SOEP 2004-2011. Results from Maximum Likelihood estimation of a conditional logit model (left column) and a latent-class conditional logit model with two mass points on the Birth coefficient (right column). Lf = weekly leisure of the woman (hours/10). $\log \mathrm{C}=$ natural logarithm of monthly disposable household income. Omitted reference categories: age $\geq 40$; neither immigrant nor 2nd generation immigrant; secondary degree or vocational training. Asymptotic standard errors clustered at the household level. *** $\mathrm{p}<0.01$, ** $\mathrm{p}<0.05,{ }^{*} \mathrm{p}<0.1$ 